\title{
Sumber informasi serta dampak penerapan pembatasan sosial dan fisik pada masa pandemi COVID-19: Studi eksploratif di Indonesia
}

\author{
Tri Rejeki Andayani \\ Program Studi Psikologi, Fakultas Kedokteran, Universitas Sebelas Maret, Surakarta, Jawa Tengah
}

\begin{abstract}
Abstrak
Sampai saat naskah ini ditulis, kasus pasien positif COVID-19 di Indonesia masih meningkat. Ini mungkin merefleksikan adanya disparitas antara pengetahuan/sikap masyarakat dengan kebijakan yang diterapkan. Penelitian ini bertujuan untuk mengeksplorasi sumber pengetahuan yang utama bagi masyarakat Indonesia dalam informasi tentang kebijakan pembatasan sosial dan fisik (social/physical distancing) dan mengungkap konsekuensi yang menyertai penerapan kebijakan tersebut. Sampel penelitian ini adalah warga negara Indonesia yang telah cakap hukum (minimal usia 17 tahun) dan aktif menggunakan gawai. Sampel penelitian sebanyak 587 partisipan yang mengisi kuesioner pertanyaan terbuka secara daring untuk mengungkap jenis media yang menjadi sumber informasi utama, situasi tersulit yang dihadapi, dan dampak dari penerapan kebijakan tersebut. Hasil analisis isi menunjukkan media sosial (online) menjadi sumber utama bagi partisipan untuk memperoleh informasi mengenai pembatasan sosial dan fisik. Beragam konsekuensi dari penerapan kebijakan tersebut dirasakan partisipan, mulai dari aspek ekonomi dalam hal ini sulitnya pemenuhan kebutuhan pokok, sampai dengan memburuknya relasi sosial yang sempat dirasakan oleh sebagian partisipan.
\end{abstract}

Kata kunci: social distancing, physical distancing, dampak kebijakan, pandemi COVID-19

\begin{abstract}
The number of COVID-19 positive cases in Indonesia remains high. This reflects a disparity between public attitudes/knowledge and public policy and regulations. This study aims to find out the main source of knowledge for the people of Indonesia in information about social policy/ physical distancing, and reveal the consequences that accompany the implementation of the policy. The samples for this research are Indonesian citizens who were legally competent (at least 17 years old) and actively used at least one type of gadget. The data from 587 participants was collected by administering an online open-ended survey to reveal the type of media that is the main source of information, the most difficult situations encountered, and the impact of implementing the policy. The results showed that social media (online) was the main source for participants to obtain information about social/physical distancing policies. Various consequences of the implementation of the policy were felt by the participants, starting from the economic aspects in this case the difficulty of meeting basic needs, to the deteriorating social relations that some participants felt.
\end{abstract}

Keywords: social distancing, physical distancing, policy impact, the COVID-19 pandemic

\section{Pendahuluan}

Sejak Indonesia masuk dalam daftar negara-negara yang terinfeksi virus Corona dan secara resmi pada awal Maret Presiden RI, Ir. Joko Widodo (Jokowi) menyampaikan adanya dua Warga Negara Indonesia (WNI) yang positif terinfeksi (Ratriani, 2020), maka sejak saat itu pula muncul berbagai upaya untuk menekan lajunya penularan virus ini. Diantaranya dengan penggunaan masker dan cuci tangan dengan sabun dan air mengalir, serta imbauan untuk menjaga jarak sosial (social distancing) dan/atau jarak fisik (physical distancing). Istilah social distancing (selanjutnya disebut pembatasan sosial) itu sendiri dikhawatirkan berdampak pada kualitas relasi sosial masyarakatnya. Oleh karena itu, WHO merevisi istilah tersebut menjadi physical distancing (selanjutnya disebut pembatasan fisik). Sesungguhnya, pentingnya menjaga jarak sosial telah diungkapkan oleh Kelso, Milne, \& Kelly (2009) bahwa jarak sosial adalah aspek perilaku manusia yang sangat penting bagi epidemiologi karena sifatnya yang universal dan setiap orang dapat mengurangi tingkat kontaknya 
dengan orang lain. Dengan cara ini, maka penularan penyakit akan berkurang.

Jika sejumlah negara seperti China, Italia, Spanyol, Perancis, Irlandia serta beberapa negara ASEAN seperti Malaysia dan Singapura yang terdampak COVID-19 telah memberlakukan lockdown sebagai cara tegas untuk menghentikan laju penyebaran COVID-19, maka Indonesia tidak termasuk di dalamnya. Ada beberapa alasan mengapa Pemerintah tidak memberlakukannya, diantaranya agar masyarakat Indonesia tidak khawatir dan panik dengan situasi ini dan untuk menjaga stabilitas ekonomi, serta sulitnya melakukan lockdown secara total pada wilayah Indonesia yang terdiri dari ribuan pulau yang tersebar. Kebijakan awalnya adalah imbauan bagi masyarakat untuk tetap tinggal di rumah, setidaknya 14 hari guna mengantisipasi penularan wabah Corona ini. Namun, baru sebulan dari pengumuman pertama di awal Maret, pada tanggal 31 Maret 2020, data resmi dari Kementerian Kesehatan Republik Indonesia (2020) mencatat sudah ada 1.528 kasus COVID-19 yang dikonfirmasi di Indonesia dan 136 kematian menyertainya.

Sejalan dengan hal itu, maka muncul Surat Edaran (SE) Menteri Dalam Negeri (SE Mendagri) Nomor 440/2622/SJ Tentang Pembentukan Gugus Tugas Percepatan Penanganan Corona Virus Desease 2019 (COVID-19) Daerah tanggal 29 Maret 2020. Adanya SE tersebut tidak serta merta menurunkan angka kasus, terbukti jumlah kasus terkonfirmasi positif COVID-19 masih fluktuatif naik turun (lihat Gambar 1).

Peningkatan jumlah kasus COVID-19 nampaknya berjalan seiring dengan adanya ketidakpatuhan masyarakat pada kebijakan tersebut. Hasil studi pendahuluan Hardjono, Andayani, dan Anggarani (2020) pada 220 partisipan menunjukkan sebanyak 160 (72,7\%) partisipan mempersepsikan masyarakat Indonesia pada umumnya memang tidak patuh pada imbauan tersebut. Terkait dengan hal itu, partisipan berharap kebijakan untuk menjaga jarak ini tidak hanya sebagai imbauan tapi ditegakkan menjadi aturan yang memiliki payung hukum dan sanksi tegas bagi pelanggar. Demikian pula riset Pelupessy, dkk (2020) pada 4.823 responden di Indonesia menemukan bahwa kebijakan untuk menjaga jarak dalam bentuk anjuran (bukan aturan) dinilai sangat efektif hanya oleh $28,6 \%$ responden saja, sementara $36 \%$ lainnya menilai efektif, dan $23,9 \%$ responden lainnya menilai hanya sedikit efektivitasnya. Hal ini sejalan pula dengan hasil penelitian kolaborasi 12 institusi di berbagai negara, termasuk di Indonesia tentang sikap dan persepsi masyarakat tentang penanganan COVID-19 menunjukkan di Indonesia tingkat kepercayaan publik terhadap pemerintah sedang dan persepsi kepatuhan terkait pencegahan penyebaran COVID-19 masih rendah (Cahyono, Milla, Subarkah, \& Yustisia, 2020).

Menyikapi hal itu, Pemerintah kemudian mengeluarkan Peraturan Pemerintah Nomor 21 Tahun 2020 tentang Pembatasan Sosial Berskala Besar Dalam Rangka Percepatan Penanganan Corona Virus Desease 2019 (COVID-19) yang mengacu pada Undang-undang Nomor 6 Tahun 2018 tentang Kekarantinaan Kesehatan. Penerapan secara berkala di beberapa wilayah Indonesia terbukti mampu menekan angka kasus Corona di beberapa kota saja, namun di sebagian wilayah lainnya tetap saja meningkat setelah penerapan aturan ini dilonggarkan.

Merespon kebijakan tersebut, penelitian lanjutan yang dilakukan Pelupessy, dkk (2020) tentang Karantina Wilayah yang dilakukan pada 4.823 responden di Indonesia menemukan bahwa penilaian terhadap efektivitas anjuran untuk menjaga jarak ini dinilai oleh hampir separuh $(43 \%)$ responden sebagai akibat dari faktor tingkat pengetahuan dan pemahaman. Dengan kata lain, tingkat pengetahuan dan pemahaman seseorang akan berdampak pada tingkat kepatuhan dan tanggung jawab terkait dengan Pandemi COVID-19.

\section{Gambar 1.}

Grafik Perkembangan Kasus Terkonfirmasi Positif COVID-19 Per-Hari pada awal April 2020

(Sumber Data: https://covid19.go.id/)

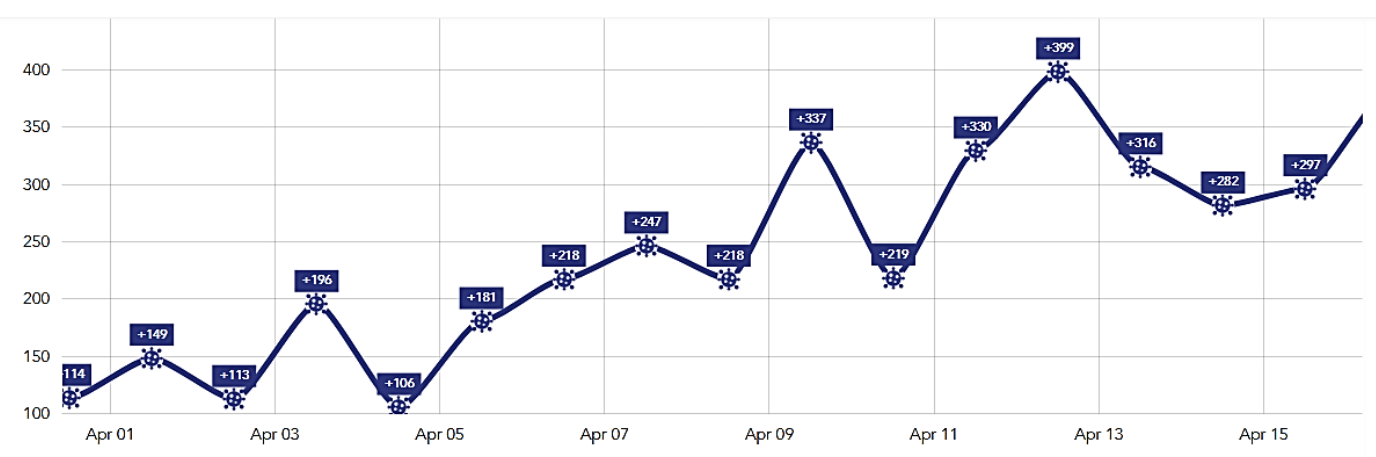


Studi cross-sectional berbasis daring selama MaretApril 2020 yang dilakukan Ferdous, dkk (2020) di Bangladesh menunjukkan dari 2017 partisipan berusia 12-64 tahun terdapat 48,3\% memiliki pengetahuan yang lebih akurat tentang COVID19 , sedangkan dari sikap menunjukkan $62,3 \%$ memiliki sikap positif, dan 55,1\% lebih sering menerapkan praktik pencegahan COVID-19. Demikian survei daring cross-sectional terhadap 1.034 penduduk AS berusia 18 tahun ke atas yang dilakukan Clements (2020) pada Maret 2020 menunjukkan pengetahuan tentang COVID-19 memengaruhi perilaku membeli lebih banyak barang dari biasanya, keputusan menghadiri pertemuan besar, dan penggunaan masker medis.

Realitas tersebut mendorong munculnya pertanyaan tentang sumber informasi utama apa yang sebetulnya digunakan masyarakat Indonesia untuk memperoleh informasi, serta meningkatkan pengetahuan dan pemahamannya tentang COVID-19 berikut juga kebijakan yang menyertainya. Selain itu, penelitian ini juga berusaha mengeksplorasi aspek tersulit yang dihadapi masyarakat saat menerapkan kebijakan untuk menjaga jarak tersebut. Dari situ, kita bisa memahami dampak penerapan kebijakan tersebut pada relasi sosialnya, karena aspek ini yang dikhawatirkan turut terdampak akibat kebijakan tersebut.

\section{Metode Penelitian}

\section{Desain dan prosedur}

Desain penelitian ini adalah studi kualitatif eksploratif. Target populasi penelitiannya merupakan warga negara Indonesia yang telah cakap hukum (minimal usai 17 tahun) dan aktif menggunakan gawai. Survei secara daring (online) ini berlangsung pada rentang tiga hari (27-29 Maret 2020). Sampel atau partisipan dipilih dengan teknik incidental sampling, dan memperoleh sampel sebanyak 587 orang dengan usia rata-rata $27,26(S D=12,04)$. Pengumpulan data dalam survei daring tersebut dengan kuesioner pertanyaan terbuka untuk menggali pengalaman partisipan dalam pembatasan sosial dan fisik, baik dari segi sumber berita, situasi yang menurut partisipan paling sulit untuk diterapkan pembatasan sosial, maupun dampak dari kebijakan tersebut terutama pada relasi sosial partisipan.

\section{Analisis dan Interpretasi}

Data kualitatif dianalisis dengan teknik analisis isi dengan cara pengkodean, mulai dari open coding, lalu axial coding, dan yang terakhir selective coding (Corbin \& Strauss, 1990). Tahap open coding menemukan kata kunci yang memi- liki makna, memilah, membandingkan, dan memasukkan dalam kategori awal sebagai wadah kata kunci yang relevan satu sama lain. Tahap axial coding untuk menyusun keterkaitan antara kategori yang telah dibuat berdasarkan open coding sebelumnya. Tahap ini mulai memanfaatkan paradigma pengkodean seperti kondisi atau konteks untuk melihat hubungan sebab akibat, interaksi antar kategori dan konsekuensinya. Lalu tahap selective coding merupakan proses seleksi kategori inti atau menentukan kategori utama. Proses ini dilakukan dengan menghubungkan secara sistematis ke kategori-kategori lain, dan menguji validasi hubungan, memasukkannya ke dalam kategori lebih lanjut yang diperlukan sebagai upaya perbaikan dan pengembangan. Untuk interrater reliability melibatkan dua pihak saja, karena mengacu pada Gwet (2014) bahwa keterlibatan orang ketiga hanya dibutuhkan ketika muncul perbedaan pendapat dari kedua rater saat menentukan kategorisasi.

\section{Hasil Penelitian dan Diskusi}

Karakteristik partisipan dikategorikan berdasarkan kelompok usia, jenis kelamin, dan tingkat pendidikan, serta pekerjaan (lihat Tabel 1). Dari hasil pengkodean pada respon partisipan yang ratarata berupa respon tunggal, maka diperoleh tiga kategori utama dari jenis media yang menjadi sumber utama/pertama bagi partisipan dalam memeroleh informasi mengenai kebijakan pembatasan sosial dan fisik. Hasil akhir kategorisasi menunjukkan media sosial mendominasi sebagai sumber informasi (lihat Tabel 2).

Sementara dari segi bentuk aktivitas atau kegiatan yang paling sulit bagi partisipan untuk menjaga jarak fisik atau sosial adalah kegiatan yang berkaitan dengan pemenuhan kebutuhan sehari-hari, yakni kebutuhan pokok, bahan bakar minyak (BBM), kuota, dan keperluan berobat. Kategori selanjutnya adalah aktivitas yang bersifat untuk kesenangan, lalu diikuti dengan aktivitas yang terkait dengan pembelajaran, pekerjaaan, kegiatan agama dan sosial kemasyarakatan, serta ke giatan bersama keluarga atau kerabat (silahkan lihat Tabel 3).

Meskipun kegiatan agama dan sosial kemasyarakatan tidak terlalu menonjol secara kuantitas, tetapi dari uraian jawaban beberapa partisipan ditemukan fakta menarik, terutama pada partisipan perempuan. Keputusan untuk menjaga jarak saat ada berita kedukaan datang sama sulitnya dengan mengambil keputusan untuk datang atau tidak di pernikahan. Apalagi jika yang mengalami kedukaan ataupun yang punya hajat tersebut masih kerabat atau tetangga dekat. 
Tabel 1.

Karakteristik Partisipan (N=567)

\begin{tabular}{llrr}
\hline & Karakteristik & Jumlah & Persentase (\%) \\
\hline \multirow{3}{*}{ Usia } & Remaja (12-25 tahun) & 413 & 70,4 \\
& Dewasa (26-45 tahun) & 90 & 15,3 \\
& Lansia (46-65 tahun) & 84 & 14,3 \\
\hline \multirow{2}{*}{ Jenis Kelamin } & Laki-laki & 154 & 26,2 \\
& Perempuan & 433 & 73,8 \\
\hline \multirow{3}{*}{ Pendidikan } & Dasar (SD-SMP) & 9 & 1,5 \\
& Menengah (SMA sederajat) & 334 & 56,9 \\
& Sarjana (Diploma \& S1) & 106 & 18,1 \\
& Pascasarjana (S2 \& S3) & 138 & 23,5 \\
\hline \multirow{3}{*}{ Pekerjaan } & Pelajar/Mahasiswa & 421 & 71,7 \\
& Guru/Dosen & 162 & 27,6 \\
& BUMN/Swasta & 4 & 7,0 \\
\hline
\end{tabular}

Tabel 2.

Kategorisasi Tema Terkait dengan Media Informasi Utama

\begin{tabular}{lrrrrrr}
\hline \multirow{2}{*}{ Kategorisasi (tema utama, subtema) } & \multicolumn{2}{c}{ Laki-laki } & \multicolumn{2}{c}{ Perempuan } & \multicolumn{2}{c}{ Total } \\
\cline { 2 - 7 } 1. Media Sosial/Internet & Jml & $\mathbf{9}$ & Jml & \multicolumn{1}{c}{$\mathbf{1 0}$} & \multicolumn{1}{c}{ Jml } & \multicolumn{1}{c}{$\mathbf{0}$} \\
a. Media sosial & $\mathbf{1 0 0}$ & $\mathbf{1 7}$ & $\mathbf{2 8 5}$ & $\mathbf{4 8 , 6}$ & $\mathbf{3 8 5}$ & $\mathbf{6 5 , 6}$ \\
b. Internet/laman Web/Online & 56 & 9,5 & 158 & 26,9 & 214 & $\mathbf{3 6 , 5}$ \\
c. Instagram & 20 & 3,4 & 57 & 9,7 & 77 & $\mathbf{1 3 , 1}$ \\
d. Whatsapp & 13 & 2,2 & 31 & 5,3 & 44 & $\mathbf{7 , 5}$ \\
e. Twitter & 6 & 1,0 & 16 & 2,7 & 22 & $\mathbf{3 , 7}$ \\
f. Youtube & 2 & 0,3 & 18 & 3,1 & 20 & $\mathbf{3 , 4}$ \\
g. LINE & 1 & 0,2 & 2 & 0,3 & 3 & $\mathbf{0 , 5}$ \\
h. Facebook & 0 & 0,0 & 2 & 0,3 & 2 & $\mathbf{0 , 3}$ \\
i. Google & 2 & 0,3 & 0 & 0,0 & 2 & $\mathbf{0 , 3}$ \\
2. Media lain & 0 & 0,0 & 1 & 0,2 & 1 & $\mathbf{0 , 2}$ \\
a. Televisi & $\mathbf{4 1}$ & $\mathbf{7 , 0}$ & $\mathbf{1 0 8}$ & $\mathbf{1 8 , 4}$ & $\mathbf{1 4 9}$ & $\mathbf{2 5 , 4}$ \\
b. Berita/Berita Corona & 15 & 2,6 & 54 & 9,2 & 69 & $\mathbf{1 1 , 8}$ \\
c. Media massa/Koran & 13 & 2,2 & 32 & 5,5 & 45 & $\mathbf{7 , 7}$ \\
d. Media elektronik & 10 & 1,7 & 16 & 2,7 & 26 & $\mathbf{4 , 4}$ \\
e. Buku/Jurnal & 1 & 0,2 & 4 & 0,7 & 5 & $\mathbf{0 , 9}$ \\
Respon merujuk tempat & 2 & 0,3 & 2 & 0,3 & 4 & $\mathbf{0 , 7}$ \\
a. Kampus/sekolah & $\mathbf{1 3}$ & $\mathbf{2 , 2}$ & $\mathbf{4 0}$ & $\mathbf{6 , 8}$ & $\mathbf{5 3}$ & $\mathbf{9 , 0}$ \\
b. Indonesia & 10 & 1,7 & 32 & 5,5 & 42 & $\mathbf{7 , 2}$ \\
c. Rumah & 1 & 0,2 & 2 & 0,3 & 3 & $\mathbf{0 , 5}$ \\
d. China/Wuhan & 1 & 0,2 & 1 & 0,2 & 2 & $\mathbf{0 , 3}$ \\
e. Solo & 1 & 0,2 & 1 & 0,2 & 2 & $\mathbf{0 , 3}$ \\
f. Asrama/kos & 0 & 0,0 & 2 & 0,3 & 2 & $\mathbf{0 , 3}$ \\
Total & 0 & 0,0 & 2 & 0,3 & 2 & $\mathbf{0 , 3}$ \\
\hline
\end{tabular}

"Paling susah kalau ada tetangga dekat atau saudara yang meninggal" (S.168/P/36).

"Situasi sulit saat harus takziyah" [mendatangi rumah orang yang sedang mengalami kedukaan karena kematian] (S.522/L/47).

"Sulitnya jaga jarak kalau jadi panitia mantenan [resepsi pernikahan]. Apalagi kadhung etuk seragam [sudah terlanjur mendapat seragam]" (S.016/P/47).
Jika perempuan lebih merasa sulit menerapkan pembatasan sosial dan fisik dalam hal sosial kemasyarakatan, maka situsi yang sulit bagi laki-laki adalah dalam hal kegiatan ibadah, terutama saat harus meninggalkan ibadah sholat Jumat dan/atau sholat berjamaah lima waktu lain yang biasanya rutin dikerjakan di masjid.

"Meninggalkan kebiasaan sholat berjamaah di mushola" (S.334/L/56).

"Susahnya tidak bisa sholat berjamaah di masjid" (S.368/L/32). "Ninggal jumatan [meninggalkan sholat Jumat]" (S.575/L/50.) 
Demikian pula bagi nonmuslim, meninggalkan kebiasaan ibadah ke gereja terasa sulit bagi partisipan meskipun itu bisa membantu memutus mata rantai penyebaran COVID-19.

\section{"Susahnya kalau ibadah di Gereja" (S.035/P/19). \\ "Sembahyang di Gereja [susah]" (S.273/L/21).}

Menariknya, kekhawatiran akan terganggunya relasi sosial akibat perberlakuan pembatasan sosial dan fisik tidak terjadi pada sebagian besar partisipan dalam penelitian ini. Sebanyak $326(55,5 \%)$ partisipan mengaku bahwa kebijakan dengan istilah lama (menjaga jarak sosial) ataupun istilah baru (menjaga jarak fisik) ternyata tidak mengganggu relasi sosialnya, baik dengan keluarga, teman, maupun masyarakat sekitar. Sementara $261(45,5 \%)$ lainnya mengaku hal itu sempat berdampak pada memburuknya relasi sosial partisipan dengan orang lain. Dari 261 tersebut, terdapat 161 partisipan terganggu relasinya dengan orang lain yang ada di lingkungan pekerjaan atau pendidikan dan kampus, lalu 44 partisipan terganggu relasinya dengan anggota keluarga, dan ada 38 partisipan terganggu relasi sosialnya dengan masyarakat sekitar, serta 18 partisipan terganggu relasi sosial lainnya (lihat Tabel 4).

Hasil penelitian ini menunjukkan media sosial sebagai arus utama dalam hal penyebaran informasi tentang COVID-19. Kemajuan teknologi informasi berupa media massa daring dan media sosial ini mau tidak mau telah menggeser peran media cetak dan media elektronik lain, seperti koran atau televisi. Terbukti hanya 4,4\% dari 587 partisipan yang masih memanfaatkan surat kabar cetak (koran) sebagai sumber informasi COVID-19 dan segala kebijakan yang menyertainya. Sementara televisi masih menjadi pilihan bagi $11,8 \%$ partisipan, meskipun angka ini jauh di bawah dari penggunaan media sosial. Temuan ini sejalan dengan penelitian McGowan, dkk (2012) bahwa media sosial bisa menjadi sarana yang efektif dan menjadi sumber informasi yang efisien untuk mendapatkan pengetahuan medis dan mengikuti perkembangan informasinya. Demikian pula penelitian Triyaningsih (2020) juga menunjukkan media sosial menjadi rujukan utama bagi masyarakat untuk mendapat informasi mengenai virus Corona.

Pemilihan media sosial sebagai rujukan utama tentu dapat dipahami sebagai salah satu konsekuensi dari penerapan kebijakan menjaga jarak fisik dan pembatasan sosial berskala besar (PSBB). Hal ini juga tentu berbeda dengan pertu- karan komunikasi secara langsung. Penelitian Ahmad \& Murad (2020) menunjukkan pada saat lockdown diberlakukan di Iraq, maka orang-orang Kurdi memilih menggunakan platform media sosial untuk mendapatkan informasi tentang COVID-19. Demikian pula di Nigeria, platform media sosial seperti Twitter, Facebook, dan berbagai situs website memudahkan warga mereka mengakses dan menyebarkan informasi mengenai COVID-19 (Ngozika, Anikwenze, \& Isiani, 2020). Penelitian Li, Chandra, dan Kapucu (2020) telah menunjukkan bahwa media tidak hanya membantu pemerintah pusat memantau kinerja penanganan COVID-19 di pemerintah daerah, tetapi juga membantu pemerintah mengidentifikasi kebutuhan warga secara tepat waktu dan merespon secara cepat. Argumentasi ini diperkuat penelitian terdahulu tentang pemanfaatan medsos yang dilakukan McGowan, dkk (2012) pada 485 dokter di AS. Hasil penelitiannya menunjukkan 279 dari 485 responden (57,5\%) menganggap media sosial sangat bermanfaat, menarik, dan media terbaik untuk mendapatkan informasi terkini dan berkualitas dan 291 dari 485 (60\%) menyatakan hal itu dapat meningkatkan kualitas pelayanan pada pasiennya.

Selain memanfaatkan media sosial untuk mendapatkan atau berbagi informasi tentang COVID-19, media daring juga digunakan sebagai sarana bersosialisasi dan berinteraksi. Hasil penelitian Yuliarti (2020) menunjukkan adanya interaksi sosial dalam masa krisis selama pandemi COVID-19 lebih banyak dilakukan melalui komunikasi secara daring. Pemanfaatan media sosial untuk membangun relasi sosial juga diterapkan oleh komunitas Palang Merah Amerika (American Red Cross) dalam menjalin relasi yang kuat dan langgeng dengan publik (Brione, dkk, 2011).

Pada dasarnya, manusia secara inheren memiliki kebutuhan untuk selalu terhubung dan pada umumnya berkeyakinan bahwa bahwa pembatasan jarak untuk mencegah penularan dan penyebaran COVID-19 tidak lantas membatasi relasi sosialnya dengan orang lain. Hal inilah yang mendorong partisipan memilih cara untuk tetap bersosialisasi secara jarak jauh. Hubungan sosial dapat dilakukan dengan memanfaatkan teknologi komunikasi, seperti telepon, video call, atau melalui media sosial daring lainnya. Peningkatan pemanfaatan komunikasi bermedia melalui media sosial tersebut mendukung fakta bahwa penerapan social distancing yang semula dikhawatirakn akan berdampak pada relasi sosial tidak dirasakan mayoritas partisipan. Sebanyak 55,5\% (326) partisipan mengaku penerapan pembatasan sosial dan fisik tidak sampai mengganggu relasinya dengan orang lain. 
Tabel 3.

Kategorisasi tema dari situasi tersulit yang menyertai penerapan kebijakan

\begin{tabular}{|c|c|c|c|c|c|c|c|}
\hline \multirow{2}{*}{\multicolumn{2}{|c|}{ Kategorisasi (tema utama, subtema) }} & \multicolumn{2}{|c|}{ Laki-laki } & \multicolumn{2}{|c|}{ Perempuan } & \multicolumn{2}{|c|}{ Total } \\
\hline & & Jml & $\%$ & Jml & $\%$ & Jml & $\%$ \\
\hline & Pemenuhan Kebutuhan Utama & 40 & 6,8 & 191 & 32,5 & 231 & 39,4 \\
\hline & a. Belanja harian/rumah tangga & 7 & 1,2 & 78 & 13,3 & 85 & 14,5 \\
\hline & b. Belanja kebutuhan pokok & 19 & 3,2 & 59 & 10,1 & 78 & 13,3 \\
\hline & c. Makan/jajan & 10 & 1,7 & 42 & 7,2 & 52 & 8,9 \\
\hline & d. ATM/BBM & 2 & 0,3 & 5 & 0,9 & 7 & 1,2 \\
\hline & e. Kuota/sinyal/Wi-fi & 2 & 0,3 & 4 & 0,7 & 6 & 1,0 \\
\hline & f. Berobat & 0 & 0,0 & 3 & 0,5 & 3 & 0,5 \\
\hline & Bersenang-senang & 26 & 4,4 & 39 & 6,6 & 65 & 11,1 \\
\hline & a. Kumpul teman & 9 & 1,5 & 19 & 3,2 & 28 & 4,8 \\
\hline & b. Olahraga/hobi & 11 & 1,9 & 4 & 0,7 & 15 & 2,6 \\
\hline & c. Nongkrong/main & 4 & 0,7 & 7 & 1,2 & 11 & 1,9 \\
\hline & d. Wisata/traveling/jalan-jalan & 2 & 0,3 & 6 & 1,0 & 8 & 1,4 \\
\hline & e. Ketemu pacar & 0 & 0,0 & 3 & 0,5 & 3 & 0,5 \\
\hline & Pembelajaran & 19 & 3,2 & 45 & 7,7 & 64 & 10,9 \\
\hline & a. Penyelesaian Tugas Akhir & 7 & 1,2 & 15 & 2,6 & 22 & 3,7 \\
\hline & b. Kuliah/belajar & 6 & 1,0 & 13 & 2,2 & 19 & 3,2 \\
\hline & c. Tugas kelompok/rapat KKN & 3 & 0,5 & 10 & 1,7 & 13 & 2,2 \\
\hline & d. Praktikum & 3 & 0,5 & 7 & 1,2 & 10 & 1,7 \\
\hline & Pekerjaan & 18 & 3,1 & 39 & 6,6 & 57 & 9,7 \\
\hline & a. Bekerja & 7 & 1,2 & 13 & 2,2 & 20 & 3,4 \\
\hline & b. Mengajar/menguji/membimbing & 4 & 0,7 & 12 & 2,0 & 16 & 2,7 \\
\hline & c. Transaksi jual beli & 2 & 0,3 & 8 & 1,4 & 10 & 1,7 \\
\hline & d. Melayani pasien & 1 & 0,2 & 3 & 0,5 & 4 & 0,7 \\
\hline & e. Kendaraan umum & 3 & 0,5 & 1 & 0,2 & 4 & 0,7 \\
\hline & f. Rapat/relasi sejawat & 1 & 0,2 & 2 & 0,3 & 3 & 0,5 \\
\hline & Agama \& Sosial Kemasyarakatan & 26 & 4,4 & 30 & 5,1 & 56 & 9,5 \\
\hline & a. Ibadah di Masjid atau Gereja & 15 & 2,6 & 9 & 1,5 & 24 & 4,1 \\
\hline & b. Sosialisasi & 6 & 1,0 & 10 & 1,7 & 16 & 2,7 \\
\hline & c. Takziyah/kegiatan sosial & 3 & 0,5 & 4 & 0,7 & 7 & 1,2 \\
\hline & d. Pernikahan/kondangan & 0 & 0,0 & 5 & 0,9 & 5 & 0,9 \\
\hline & e. Pengajian & 2 & 0,3 & 2 & 0,3 & 4 & 0,7 \\
\hline & Aktivitas Bersama Keluarga/Kerabat Dekat & 6 & 1,0 & 25 & 4,3 & 31 & 5,3 \\
\hline & a. Kumpul keluarga & 4 & 0,7 & 14 & 2,4 & 18 & 3,1 \\
\hline & b. Silaturahmi/mudik/mengunjungi & 2 & 0,3 & 7 & 1,2 & & \\
\hline & orang tua/kerabat & & & & & 9 & 1,5 \\
\hline & c. Relasi dengan anak & 0 & 0,0 & 3 & 0,5 & 3 & 0,5 \\
\hline & d. Relasi dengan pasangan & 0 & 0,0 & 1 & 0,2 & 1 & 0,2 \\
\hline & Tidak ada & 19 & 3,2 & 64 & 10,9 & 83 & 14,1 \\
\hline & Total & 154 & 26,2 & 433 & 73,8 & 587 & 100,0 \\
\hline
\end{tabular}

Selain faktor pemanfaatan media sosial sebagai sarana berjalin komunikasi dan relasi, maka faktor pemahaman dari orang-orang di sekitarnya tentang pentingnya menjaga jarak satu sama lain turut berperan dalam menerima realitas jarak sosial ini. Seperti yang diungkapkan oleh beberapa partisipan berikut ini.

"Tidak ada, sebab pada umumnya temen-temen komunitas sepeda sudah memahaminya" (S.54/L/57).

"Tidak ada, karena semua sudah mengerti" (S.455/L/22).
"Tidak ada, karena orang dekat cukup memahami kondisi yang ada" (S.473/L/29).

"Tidak ada, karena karena samasama mengerti pentingnya social distancing untuk saat ini." (S.564/P/19).

Dengan kata lain, faktor pemahaman dan pemanfaatan media sosial sebagai media komunikasi dan berinteraksi sosial di masa pandemi COVID-19 menyebabkan sebagian partisipan tidak terganggu relasi sosialnya akibat kebijakan menjaga jarak fisik dan pembatasan sosial ini. 
"Alhamdulillah, tidak mengganggu hubungan sosial, karena interaksi bisa dilakukan secara online [daring]" (S.543/P/40).
"Jaga jarak sosial yang harus diterapkan enggak merusak hubungan kok, malah mempererat karena sering kontak lewat hp, cuma kuota jadi terkuras."(S.506/P/25)

Tabel 4.

Hasil Akhir Kategorisasi Tema dari Dampak Kebijakan pada Relasi Sosial Partisipan

\begin{tabular}{|c|c|c|c|c|c|c|c|}
\hline \multirow{2}{*}{\multicolumn{2}{|c|}{ Kategorisasi (tema utama, subtema) }} & \multicolumn{2}{|c|}{ Laki-laki } & \multicolumn{2}{|c|}{ Perempuan } & \multicolumn{2}{|c|}{ Total } \\
\hline & & Jml & $\%$ & Jml & $\%$ & Jml & $\%$ \\
\hline 1. & Tidak ada & 83 & 14,1 & 243 & 41,4 & 326 & 55,5 \\
\hline 2. & Relasi di pekerjaan/kantor/kampus & 42 & 7,2 & 119 & 20,3 & 161 & 27,4 \\
\hline & a. Teman/kawan & 20 & 3,4 & 65 & 11,1 & 85 & 14,5 \\
\hline & b. Teman kampus/organisasi & 7 & 1,2 & 16 & 2,7 & 23 & 3,9 \\
\hline & a. Rekan kerja/karyawan & 6 & 1,0 & 16 & 2,7 & 22 & 3,7 \\
\hline & b. Murid/mahasiswa & 3 & 0,5 & 9 & 1,5 & 12 & 2,0 \\
\hline & c. Pengajar/Pembimbing & 2 & 0,3 & 6 & 1,0 & 8 & 1,4 \\
\hline & d. Perkuliahan & 2 & 0,3 & 6 & 1,0 & 8 & 1,4 \\
\hline & e. Pasien/klien & 2 & 0,3 & 1 & 0,2 & 3 & 0,5 \\
\hline & Relasi di keluarga & 13 & 2,2 & 31 & 5,3 & 44 & 7,5 \\
\hline & a. Kerabat/saudara & 5 & 0,9 & 10 & 1,7 & 15 & 2,6 \\
\hline & b. Keluarga & 4 & 0,7 & 8 & 1,4 & 12 & 2,0 \\
\hline & c. Anak/Anak \& suami & 2 & 0,3 & 6 & 1,0 & 8 & 1,4 \\
\hline & d. Orang tua & 1 & 0,2 & 5 & 0,9 & 6 & 1,0 \\
\hline & e. Mertua & 1 & 0,2 & 2 & 0,3 & 3 & 0,5 \\
\hline 4. & Relasi di masyarakat & 11 & 1,9 & 27 & 4,6 & 38 & 6,5 \\
\hline & a. Tetangga & 4 & 0,7 & 14 & 2,4 & 18 & 3,1 \\
\hline & b. Orang sekitar & 2 & 0,3 & 8 & 1,4 & 10 & 1,7 \\
\hline & c. Masyarakat & 5 & 0,9 & 4 & 0,7 & 9 & 1,5 \\
\hline & d. Kelompok sosial/agama & 0 & 0,0 & 1 & 0,2 & 1 & 0,2 \\
\hline 5. & Lain-lain & 5 & 0,9 & 13 & 2,2 & 18 & 3,1 \\
\hline & a. Pacar/teman dekat & 4 & 0,7 & 12 & 2,0 & 16 & 2,7 \\
\hline & b. Driver ojek online & 0 & 0,0 & 1 & 0,2 & 1 & 0,2 \\
\hline & c. Media sosial & 1 & 0,2 & 0 & 0,0 & 1 & 0,2 \\
\hline & Total & 154 & 26,2 & 433 & 73,8 & 587 & 100,0 \\
\hline
\end{tabular}

Tingginya angka penggunaan media sosial dalam penelitian ini tidak terlepas dari karakteristik partisipan yang didominasi remaja (12-25 tahun), yakni sebesar 413 (70,4\%) dari 587 partisipan. Hasil survei tentang komunikasi remaja melalui media sosial, termasuk situs jejaring sosial seperti Facebook dan MySpace, micro-blogging seperti Twitter dan Tumblr, blog, teks atau obrolan suara selama online game multipemain, dan komunikasi virtual lainnya pada 1.030 anak usia 13 hingga 17 tahun yang dilakukan secara daring oleh Knowledge Networks: A Gfk Company menunjukkan 54\% remaja mengaku penggunaan media sosial atau jejaring sosial telah membantu remaja merasa lebih terhubung dengan keluarga dan temannya. Khususnya dalam hal pertemanan, $88 \%$ sampel mengatakan jejaring sosial telah membantunya tetap berhubungan dengan teman, sementara 69\% mengatakan itu telah membantu lebih mengenal siswa lain di sekolah, dan 57\% mengatakan menemukan teman baru melalui jejaring sosial, dan di antara semua bentuk komunikasi digital, pesan melalui teks merupakan jenis yang paling banyak digunakan remaja, dengan alasan mudah, cepat, dan memungkinkan merekan melakuka lebih dari satu hal dalam satu waktu (Rideout, 2012).

Penggunaan media sosial, salah satunya Whatsapp (WA) di kalangan remaja atau mahasiswa juga telah diteliti Amna (2018) yang mengungkap bahwa WA yang pada awalnya sebatas pesan teks pendek atau percakapan telah bertransformasi sebagai media transfer informasi yang lebih interaktif. Komunikasi tidak hanya menggunakan pesan teks, tetapi juga suara, gambar, dan video. Terkait dengan penanganan penyebaran COVID-19, maka banyak beredar flyer, video, dan bentuk visual lainnya di media sosial termasuk WA. Tidak hanya berperan sebagai media informasi yang bersifat edukatif, WA Group (WAG) ini pun dapat berfungsi untuk membangun solidaritas peduli COVID-19 dan memudahkan masyarakat mewujudkan kepeduliannya, 
melakukan koordinasi dan aksi sosial bagi yang terkena dampak dari COVID-19.

Ini sejalan dengan perspektif Uses and Gratification Theory yang dikemukakan Katz, Blumler, \& Gurevitch pada tahun 1974 (Nurudin, 2003) bahwa manusia atau khalayak merupakan konsumen media yang aktif dan memiliki otonomi untuk memilih atau mengunakan jenis media yang dapat digunakan untuk memenuhi kebutuhannya. Konsep khalayak yang aktif ini menurut Blumler (1979, dalam Rakhmat, 2007) menekankan pada aspek utility atau penggunaannya, intentionally atau kesengajaan dan kesadaran dalam mengkonsumsi isi atau konten media, selectivity atau selektivitas dalam menentukan minat dan preferensi yang dimilikinya, serta imperviousness to influence atau ketahanan terhadap pengaruh dari media itu sendiri.

Terkait dengan dampak penerapan pembatasan sosial dan fisik atau situasi tersulit yang dirasakan partisipan dalam masa pandemi mayoritas adalah alasan ekonomi, seperti sulitnya memenuhi kebutuhan pokok dan kebutuhan lainnya yang menunjang hal tersebut. Situasi ini mendorong munculnya beragam tindakan dan gerakan baik secara individul maupun secara kolektif yang merepresentasikan eksistensi solidaritas sosial dalam masyarakat (Arditama \& Lestari, 2020). Adanya solidaritas sosial selama pandemi diharapkan mampu meningkatkan partisipasi aktif masyarakat di tengah keterbatasan fisik, keterbatasan mobilitas, dan keterbatasan sumber daya akibat COVID-19 (Cahyono, 2020). Oleh karena itu, ada baiknya selama masa pandemi ini pemerintah tidak hanya memanfaatkan media sebagai alat untuk menginformasikan peningkatan kasus COVID-19, tetapi juga mengkomunikasikan informasi yang menghadirkan model-model perilaku positif. Sepertinya halnya yang dilakukan pemerintah China yang menggunakan media sosial untuk mempromosikan keterlibatan warga negara selama krisis COVID-19 (Chen, dkk, 2020). Platform media sosial juga tidak hanya untuk mempercepat kecepatan upaya bantuan tetapi juga mempermudah mobilisasi warga Wuhan dan organisasi nonprofit untuk mendukung pemerintah China dalam memberikan respon dan melakukan upaya pemulihan (Li, Chandra, \& Kapucu, 2020).

Sebagai masyarakat Indonesia yang dikenal dengan kehidupannya yang guyup, rukun dan juga religius, maka hal tersulit yang dirasakan sebagian partisipan dalam penerapan kebijakan adalah menyangkut aspek beribadatan (agama) dan kegiatan sosial kemasyarakatan. Bila dicermati lebih rinci, partisipan perempuan tampak lebih sulit menerapkan kebijakan tersebut dalam kaitannya dengan kegiatan sosial kemasyarakatan, sedangkan partisipan laki-laki dalam praktek keagamaan. Hal ini tidak terlepas dari konteks budaya masyarakat Indonesia, khususnya Jawa (Bakhri, 2018; Warto, 2016) yang pada umumnya mempraktikkan kegiatan sosial kemasyarakat seperti nyumbang atau rewang mayoritas dilakukan kaum perempuan (para ibu). Nyumbang adalah praktek memberikan sejumlah uang atau barang kepada pihak yang memiliki hajat/acara perhelatan, sedangkan rewang adalah satu bentuk perilaku prososial dalam masyarakat Jawa dengan cara memberi bantuan tenaga atau jasa pada pihak yang sedang menyiapkan, menyelenggarakan hajatan, atau perhelatan tersebut. Aktivitas nyumbang ataupun rewang ini dapat dilakukan dalam upacara perkawinan, kematian, khitanan, dan hajatan lainlain. Jika hal ini tidak dijalankan sesuai adat kebiasaannya dapat menimbulkan sanksi sosial yang lebih dirasakan oleh perempuan diban-dingkan laki-laki. Sementara dari aspek agama, kewajiban untuk menjalankan ibadah sholat lima waktu secara berjamaah di masjid, dan sholat Jumat diutamakan (wajib) bagi laki-laki muslim, bukan perempuan.

Terhambatnya relasi sosial dan komunitas dalam kegiatan sosial kemasyarakatan di masa pandemi yang lebih dirasakan perempuan dibandingkan laki-laki juga dapat dipahami dari perspektif Tend and Befriend Theory yang dikemukakan Taylor (2012). Berbeda dengan laki-laki, respon perempuan terhadap stres pada umumnya adalah berafiliasi dengan orang lain, dibandingkan dengan strategi menghindar atau menghadapi sendiri (Turton \& Chambell, 2007). Sementara dalam situasi pandemi COVID-19, pembatasan relasi sosial secara langsung justru menjadi salah satu kebijakan yang harus dipatuhi. Keadaan inilah semakin menjadi tekanan bagi perempuan dan menimbulkan ketidaknyamanan, sehingga mendorong partisipan untuk mencari jalan keluar.

Realitas ini sejalan dengan asumsi dasar dari Teori Disonansi Kognitif (Festinger, 1957, dalam Cooper, 2007) bahwa manusia pada dasarnya tidak menyukai ketidakkonsistenan atau ketidakserasian antara apa yang selama ini diyakini dengan perilaku yang dihasilkannya. Hal ini akan menimbulkan ketidaknyamanan atau yang disebut Festinger sebagai keadaan disonan. Semakin kuat ketidakkonsistenan yang dihadapi, akan semakin menggelisahkan, sehingga mendorong seseorang untuk bertindak sesuatu guna mengurangi ketidakkonsistenan tersebut. Oleh karena itu, ketidaknyaman yang dirasakan partisipan saat meninggalkan kegiatan sosial atau partisipan yang merasa gelisah saat harus meninggalkan kebiasaannya beribadah jamaah di masjid akan berusaha untuk mencapai keadaan konsonan kembali. Salah satu strateginya adalah dengan menambah elemen kognitif baru. Munculnya 
fatwa Majelis Ulama Indonesia (MUI) yang memperbolehkan muslim untuk mengganti salat Jumat dengan salat zuhur bisa jadi menjadi eleman kognitif baru tentang tata cara sholat Jumat di masa Pandemi (Fatwa MUI Nomor 14 Tahun 2020). Demikian pula dari penjelasan para pemuka agama lain, termasuk pendeta, serta seruan dari Gubernur DKI Jakarta Nomor 5 Tahun 2020 tentang Peniadaan Sementara Kegiatan Peribadatan dan Keagamaan Di Rumah Ibadah Dalam Rangka Mencegah Penyebaran Wabah COVID-19, dan Surat Edaran (SE) Walikota Surakarta Nomor 443.76/718 tentang Pembatasan Aktivitas Pertemuan Warga Terkait Pencegahan Penyebaran COVID-19 diharapkan mampu menjadi pedoman baru dalam beribadah dan bermasyarakat di masa pandemi.

Selain menambah elemen kognitif baru, maka strategi lain untuk mencapai konsonan kembali adalah dengan mengubah elemen tingkah laku dan elemen kognitif lingkungan (Festinger, 1957). Hal ini tampak pada pengalaman partisipan perempuan yang semula bingung untuk menghadiri undangan, maka dirinya akan tetap datang ke resepsi dengan menerapkan protokol kesehatan yakni membawa sendiri hand sanitizer, mengenakan masker sepanjang acara dan duduk dengan menjaga jarak satu sama lain. Demikian pula partisipan yang tetap ingin menjalan ibadah akan beribadah dengan berusaha mengubah perilakunya sesuai protokol kesehatan (Rohman, dkk, 2020).

Hasil penelitian ini menempatkan relasi di lingkungan keluarga sebagai dampak yang terkecil dari penerapan kebijakan pembatasan sosial dan fisik. Anjuran untuk tinggal di rumah selama masa pandemi tentu saja memberi kesempatan luas dan lebih lama berinteraksi bersama keluarga dibandingkan dengan masa sebelum pandemi COVID-19.

\section{Kesimpulan}

Hasil penelitian ini membuktikan bahwa peran media sosial tetap menjadi sebagai sumber utama bagi masyarakat Indonesia dalam memeroleh informasi tentang kebjiakan pembatasan sosial dan fisik. Untuk itu, kewaspadaan pada ancaman hoaks terkait COVID-19 yang beredar di media sosial perlu ditingkatkan. Di sisi lain, kontenkonten yang ada di media sosial sebaiknya tidak hanya bersifat persuasif dan edukatif tentang COVID-19, tetapi juga mempromosikan keterlibatan masyarakat dalam penanganan COVID-19. Pesan-pesan dalam imbauan atau anjuran sebaiknya juga melibatkan aspek relasional agar muncul tanggung sosial yang mendorong masyarakat semakin patuh pada protokol kesehatan karena menyadari bahwa hal ini tidak hanya berdampak pada diri sendiri tetapi juga pada orang lain. Dari segi dampak, situasi tersulit yang dihadapi mayoritas masyarakat Indonesia dalam penerapan kebijakan ini adalah aspek ekonomi. Meskipun begitu, persoalan pemenuhan kebutuhan pokok tampaknya dapat diantisipasi dengan peningkatan solidaritas sosial masyarakat, tanpa perlu melonggarkan aturan PSBB dan imbauan pembatasan sosial dan fisik.

Mengingat bahwa penelitian ini dilakukan pada masa awal pandemi COVID-19, yakni sekitar Maret 2020 saja, tentunya masih memiliki keterbatasan karena realitas yang menyertai COVID19 masih terus berkembang. Perubahan yang dinamis pada kasus pandemi, tidak hanya kewaspadaan pada ancaman hoaks tentang COVID-19, peningkatan jumlah kasus, tetapi juga dinamika perubahan bentuk anjuran dan aturan pencegahannya, serta pemberlakuannya. Demikian pula dari segi dampak, terutama dalam hal ekonomi dan relasi, bisa jadi akan meluas jika COVID-19 tidak segera diatasi karena pengabaian sikap/perilaku masyarakat itu sendiri pada anjuran dan aturan yang telah ditetapkan. Untuk itu, perlu ada kajian yang lebih mendalam tentang berbagai hal tersebut dan pada penelitian selanjutnya diharapkan dapat lebih komprehensif dan aplikatif agar kemanfaatan praktis dapat segera dirasakan.

\section{Daftar Pustaka}

Amna, A. (2018). Whatsapp (WA) dan konsep jarak sosial baru di masyarakat. Expose: Jurnal Ilmu Komunikasi, 1(2), 134. https://doi.org/10.33021/exp.v1i2.445

Bakhri, S. (2018). Resiprositas dalam Sunat poci Dan Mantu Poci Masyarakat Tegal. Jurnal Analisa Sosiologi, 7(1): 94-109. Diunduh dari https://jurnal.uns.ac.id/jas/article/view/ 19104

Bandura, A. (1971). Social learning theory. New York: General Learning Press.

Briones, R.L., Kuch, B., Liu, B.F., \& Jin, Y. (2011). Keeping up with the digital age: How the American Red Cross uses social media to build relationships. Public Relations Review, $\quad 37 \quad$ (1), 37-43. https://doi.org/10.1016/j.pubrev.2010.1 2.006

Cahyono, W., Milla, N.M., Subarkah, M. Z., \& Yustisia, W. (2020). Policy Brief 02: Partisipasi Aktif Masyarakat Untuk Memperkuat Solidaritas Sosial. Jakarta: Ikatan Psikologi Sosial.

Chen, Q., Min, C., Zhang, W., Wang, G., Ma, X., \& Evans, R. (2020). Unpacking the black box: How to promote citizen engagement through government social media during 
the COVID-19 crisis. Computers in Human Behavior, 110, 106380. https://doi.org/10.1016/j.chb.2020.1063 80

Clements, J.M. (2020). Knowledge and Behaviors Toward COVID-19 Among US Residents During the Early Days of the Pandemic: Cross-Sectional Online Questionnaire. JMIR Public Health Surveill, 6(2), 1-11. https://doi.org/10.2196/preprints.1916 1

Corbin, J. M., \& Strauss, A. (1990). Grounded theory research: Procedures, canons, and evaluative criteria. Qualitative Sociology, 13(1),3-21. https://doi.org/10.1007/bf00988593

Cooper, Joel. (2007). Cognitive Dissonance: Fifty Years of a Classic Theory. London: SAGE Publications.

Erisandi Arditama, E., \& Lestari, P. (2020). Jogo Tonggo: Membangkitkan Kesadaran Dan Ketaatan Warga Berbasis Kearifan Lokal Pada Masa Pandemi Covid-19 Di Jawa Tengah. Jurnal Pendidikan Kewarganegaraan, 8(2), 157-167. https://doi.org/10.23887/jpku.v8i2.2543 4

Ferdous, M. Z., Saiful Islam, M., Sikder, M. T., Mosaddek, A. S. M., Zegarra-Valdivia, J. A., \& Gozal, D. (2020). Knowledge, attitude, and practice regarding COVID-19 outbreak in Bangladeshi people: An online-based cross-sectional study. https://doi.org/10.1101/2020.05.26.201 05700

Fatwa MUI Nomor 14 tahun 2020 tentang Penyelenggaraan Ibadah Dalam Situasi Terjadi Wabah Covid-19.

Gwet, K.L. (2014). Handbook of Inter-rater Reliability: The Definitive Guide to Measuring the Extent of Agreement Among Raters (4th Ed). Gaithersburg: Advanced Analytics, LLC .

Hardjono, Andayani, T.R., \& Anggarani, F.K. (2020). Persepsi Masyarakat Indonesia pada Kebijakan Social Distancing: Sebagai Anjuran atau Aturan?. Laporan Studi Pendahuluan dalam Hibah Penelitian Mandiri Penugasan Covid-19. Surakarta: LPPM UNS.

Henslin, J. M. (2006). Sosiologi dengan Pendekatan Membumi. Jakarta: Erlangga.

Kelso, J.K., Milne, G.J., \& Kelly, H. (2009). Simulation suggests that rapid activation of social distancing can arrest epidemic development due to a novel strain of influenza. BMC Public Health, 9 (1). https://doi.org/10.1186/1471-2458-9117
Li, Y., Chandra, Y., \& Kapucu, N. (2020). Crisis Coordination and the Role of Social Media in Response to COVID-19 in Wuhan, China. The American Review of Public Administration, 50(6-7), 698-705. https://doi.org/10.1177/027507402094 2105

McGowan, B.S., Wasko, M., Vartabedian, B.S., Miller, R.S., Freiherr, D.D., \& Abdolrasulnia, M. (2012). Understanding the factors that influence the adoption and meaningful use of social media by physicians to share medical information. Journal of Medical Internet Research, 14(5), e117. https://doi.org/10.2196/jmir.2138

Milla, N.M. (2020). Rekonstruksi Solidaritas Sosial dalam Mengatasi Pandemi Covid19. Handout dalam Online Sharing Session \#10 HIMPSI. Jakarta: Kompartemen Pengembangan Asosiasi dan Ikatan Pengurus Pusat Himpunan Psikologi Indonesia (HIMPSI).

Ngozika A. Obi-Ani, N.A., Anikwenze, C., \& Isiani, M.C. (2020). Social media and the Covid-19 pandemic: Observations from Nigeria. Cogent Arts \& Humanities, 7(1), 1-15. https://doi.org/10.1080/23311983.2020 .1799483

Nurudin. (2003). Komunikasi Massa. Yogyakarta: Pustaka Pelajar.

Pelupessy, D., Surtiari, G.A.K. \& Tim Panel Sosial untuk Kebencanaan. (2020). Studi Sosial Covid-19: Studi 3 Karantian Wilayah. Jakarta: Gugus Tugas Penanganan Covid19.

Peraturan Pemerintah (PP) Nomor 21 Tahun 2020 tentang Pembatasan Sosial Berskala Besar Dalam Rangka Percepatan Penanganan Corona Virus Desease 2019 (Covid-19).

Rakhmat, J. (2007). Psikologi Kamunikasi. Bandung: Rosdakarya.

Ratrianai, V.R. (2020, 2 Maret). Indonesia Positif Corona, Berikut Daftar 65 Negara Terinfeksi Covid-19. Diunduh dari https://www.kompas.com/tren/read/20 20/03/02/134500465/indonesia-positifcorona-berikut-daftar-65-negaraterinfeksi-covid-19?page=all

Rideout, V. (2012). Social Media, Social Life: How Teen View Their Digital Lives: A Common Sense Media. Research Study Summer 2012. New York: Common Sense Media.

Rohman, H., Rachmaniyah, V.A., Satia, A.B., Putri, D.F., \& Hakim, L. (2020). Praktek Ibadah pada Masa Pandemi Virus Covid-19. Pamekasan: Duta Medai Publising. 
Setiati, S., \& Azwar, M.K. (2020). COVID-19 and Indonesia. Special article Acta Med Indones - Indones J Intern Med, 52(1), 84-89. Diunduh dari http://www.actamedindones.org/index.p hp/ijim/article/view/1426

Seruan Gubernur DKI Jakarta Nomor 5 tahun 2020 tentang Peniadaan Sementara Kegiatan Peribadatan dan Keagamaan Di Rumah Ibadah Dalam Rangka Mencegah Penyebaran Wabah Corona Virus Disease (COVID-19).

Surat Edaran (SE) Walikota Surakarta Nomor 443.76/718 tentang Pembatasan Aktivitas Pertemuan Warga Terkait Pencegahan Penyebaran Covid-19.

Surat Edaran Menteri Dalam Negeri (SE Mendagri) Nomor 440/2622/SJ Tentang Pembentukan Gugus Tugas Percepatan Penaganan Corona Virus Desease 2019 (Covid-19) Daerah.

Taylor, S.E. (2012). Tend and Befriend Theory. In Van Lange, P.A.M., Kruglanski, A.W., \& Higgins, E.T (Eds) Handbook of Theories of Social Psychology Vol.1, Chapter 2. London: SAGE Publication.

Triyaningsih, H. (2020). Efek Pemberitaan Media Massa Terhadap Persepsi Masyarakat Tentang Virus Corona (Studi Kasus Masyarakat di Pamekasan). Meyarsa: Jurnal Ilmu Komunikasi dan Dakwah,
1(1),1-21.

https://doi.org/10.19015/meyarsa.v1i1. 3222

Turton, S., \& Campbell, C. (2007). Tend and Befriend Versus Fight or Flight: Gender Differences in Behavioral Response to Stress Among University Students. Journal of Applied Biobehavioral Research, 10(4), 209-232.

https://doi.org/10.1111/j.17519861.2005.tb00013.x

Undang-undang Nomor 6 Tahun 2018 tentang Kekarantinaan Kesehatan.

Undang-Undang Nomor 19 Tahun 2016 tentang Perubahan atas Undang-Undang Nomor 11 Tahun 2008 tentang Informasi dan Transaksi Elektronik.

Warto. (2016). Keswadayaan Masyarakat Perdesaan melalui Gotong Royong. Jurnal Penelitian Kesejahteraan Sosial, Vol.15(3), 281-294.

Yuliarti, M. S. (2020). Interaksi Sosial dalam Masa Krisis: Berkomunikasi Online Selama Pandemi COVID-19. Prosiding Seminar Nasional Problematika Sosial Pandemi Covid-19: Membangun Optimisme di Tengah Pandemi Covid-19. Diunduh dari https://www.ojs.literacyinstitute.org/ind ex.php/prosidingcovid19/article/view/29/ 19. 